\title{
Dissonting Problems in Literary Translation
}

\section{Shirinova Raima Khakimova*}

Department of the Foreign Languages for Social Subjects and Humanities, National University of the Uzbekistan, Uzbekistan

\begin{abstract}
This article is about the problem translated the theory of cognitive phenomena dissonance referring to the idea of the role and importance of the process of translation. Literary translation cognitive dissonance examples of Uzbek writers of the French language and French writer analysis of samples taken from the works have been translated into. Studied the causes of contradictions and expressed views on ways to reduce them.
\end{abstract}

Keywords: Dissonance; Cognitive dissonance; Color; Adequate translation; Mentality; Source language; Target language; Meaning; Direct translation; Indirect translation

\section{Introduction}

To obtain an equivalence in the translation it is necessary to overcome some language barriers. One of the language barriers is related to the problem of cognitive dissonance. To reduce or eliminate cognitive dissonance in translation, it is first necessary to define the reasons why they appear. As part of our research we have distinguished 3 cases of dissonance in literary translation. In this article we examine the different perspectives on the study of these cases of dissonance.

\section{Dissonances Resulting from the Addition of the Addi- tionnel Word}

The cases of cognitive dissonance result in the translation process of the addition by the translator of unnecessary or inappropriate words or expressions. We demonstrate this with an example of the translation into French of the novel by a famous Uzbek writer Tchulpan "Ketcha va koundouz" ("Night and Day"). This novel was translated directly from the Uzbek language into French by the French translator, the scholarorientalist Stéphane Dudoignon in 2009 and published in France. It should be emphasized that this novel gave much information about the history, culture, values, traditions, national rites and festivals of the Uzbek people, and enabled French readers to discover the historical culture of the Uzbeks. At the end of the book, the translator gives an explanation of more than 100 notions of Uzbek national realities and facilitates reading to the French reader. In spite of all this, in the translation there are cognitive elements. For example, In the original: "Şahardan taşqariga less jurişi. It was only grandfather Bilan Birga (y̌şa due Bilan!) Ty̆jlarga, katta zijofatlarga qovun and fruit sajillariga Boradi. "(It redko vыxodit disabled crank. Tolbko dedom Eşonom [1]. The Stéphane Dudoignon translation: "The city he left little, only in the company of Father Ichan, for a banquet, a rich festival or the great harvests of melons in the late spring" [2]. The expression қовун ва мева сайилларига is translated as "the great harvest of melons from the end of spring." It is obvious that the translator does not know the melon festival of the Uzbeks. In Uzbekistan the fruit and vegetable collection season, ie the period of their complete ripening, falls in the middle of summer. The translator, having used the expression "the great harvests of melons of the end of spring." Did not correctly express the reality. The month of May is the last month of spring and during this month there is no harvest of melons and watermelons in Uzbekistan. National holidays linked to a season such as хосил байрами (harvest festival), мева сайли (country trip to eat fruit on the spot), лола сайли (trip to the countryside to collect tulips) are considered as The attributes having the national color. The translator must have accurate and abundant information on these things to translate well. Incorrect information leads to the difficulty of the reader's understanding of the translated work and leads to the appearance of dissonance.

The following example is taken from the news of Erkin A'zam "Pakananing ошиқ куингли" ("The loves of Courtaud"). This news was translated directly from the Uzbek language into French by Ch.Minovarov and O.Nabieva. The original text:

“- қаёққа ketyapsan?

- Ёtoқhonaga.

- Қапақа ёtoқhonaga? Do қilasan in Erdal?

- Bir tanishimning honasida turibman. Уақtincha.” [3],

La traduction:

“-Où Vas- tu maintenant?

- A l'hôtel.

- A l'hôtel? Que fait-tu là bas?"

I share a friend's room for a while." [4],

In the following example we can find the propositions of the same content.

In the original:

"IMHO this yurişda, boşing Piano x̦eç Seng cows bermaydi. Cal No more teatring. If the yotoқ-Bera potoқ

\section{In the translation}

"Without this solution, you will never have a place to live and I do not think that your theater will have the means to buy you an apartment. By waiting, you might get a hotel room from them, but that will not be enough for you "In the contexts given the translators translated the word "ётоқхона" (the home) as "the hotel". In this passage Arofat communicates to the Courtaud that she dwells temporarily in the

*Corresponding author: Shirinova Raima Khakimova, Department of the Foreign Languages for Social Subjects and Humanities, National University of the Uzbekistan, Uzbekistan, Tel: +998 7124602 24; E-mail: Raima71@mail.ru

Received July 15, 2017; Accepted July 19, 2017; Published July 25, 2017

Citation: Khakimova SR (2017) Dissonting Problems in Literary Translation. Arts Social Sci J 8: 292. doi: 10.4172/2151-6200.1000292

Copyright: $\odot 2017$ Khakimova SR. This is an open-access article distributed under the terms of the Creative Commons Attribution License, which permits unrestricted use, distribution, and reproduction in any medium, provided the original author and source are credited. 
foyer, in the room of his friend. But the French reader, as he reads these lines will have the impression that she lives in the hotel. We know that there is a big difference between a hotel and a home and in both languages these two words are not synonyms. We give the terms given in "The dictionary of the Uzbek language" and in Larousse, Robert the following interpretations.

\section{In the Uzbek language}

"Jotoq - posting jotadigan y̆rin home. Organization, muassasa, or y̆quv jurtining y̆z xodimlari, posting y̆quvci and talabalari ucun qy̆rgan and jaşajdigan. " (The home - the place, the room to live in. The establishment built by an organization, institution or educational institution for the residence of collaborators, pupils and students.) "Hotel. 1. Guest House kutiladigan. 2. Musofirlarning vaqtinca turişi ucun zihozlangan xonalardan building. "(L'hôtel 1. La maison pour accueillir les invités. 2 . Le bâtiment équipé des pièces pour la résidence temporaire des étrangers) [5]. In the French language: "Hotel. XIe ostel dwelling, logie low latin hospitale room for guests. It would then be necessary, in this case, to use the words "home" or "university residence", because these words express exactly the will of the author. The following example is taken from Charles Perrault's fairy tale "Les contes de Perrault" ("The Tales of the Mother Goose"). The Uzbek translator Moukhiddin Omon published in 2013 the collection "The fairest fairy tales". In this collection there is the translation of the fairy tales of several known storytellers among which the fairy tales of Charles Perrault. In the course of our research we have observed the phenomena of dissonance appearing because of the unavoidable insertion of a word or expressions in the text of the translation of the fairy tale.

\section{In the original}

"One day his mother made cakes and said to his daughter:" Go and see how your grandmother is sick and carry a cake and a pot of butter.

\section{The translation of Moukhiddin Omon}

"I Savatçaga for buvijoning kulça elegance, tours dorivor giyoxłlar, ASALA ozroқ xamda shishas by̆za solib қy̆yganman. Ular zudlik Piano olib Borg. Before analyzing the translation of the text, we found it necessary to pay attention to the translation of this fairy tale into the intermediate language, that is to say into the Russian language, of which it was indirectly translated into The Uzbek language.

\section{Translation into the intermediate language}

"Once baked pie mother and daughter said:-converges-Ka you, Little Red Riding Hood to her grandmother, she pulled down the pot pie and butter, so find out if she is healthy". In the original text it is said that Red Riding Hood should carry to the grandmother a cake and a pot of butter ". But in the translation the translator replaced a "pot of butter" with a "bottle of bouza". However, "bouza" is an alcoholic beverage made from rice, barley. The translator not only replaced a "pot of butter" with a "bottle of bouza," but added the words "of various medicinal plants, a little honey," which are absent in the original. One of the criteria for defining the quality of adequate translation is the proportion of form and content. For one of the earliest theorists of translation Ciceron (110-43 BC), the role of the translator is not to align the equivalents of the words of the text like coins, but to give the sum of their contents. The following example is taken from the translation of the fairy tale "Puss in Boots".

\section{In the original}

He put his and the sow thistles in his bag, and pretending that he was dead. He waited until some young rabbit would stick himself into his bag to eat the contents. "

\section{Translation into the inter médiate language:}

In his sack he put bran and cleft cabbage and stretched out on the ground, as if dead, Steels wait for some young rabbit, is not yet versed in the tricks of the light, climbed in, eat a bag that was put there.

\section{The translation of Moukhiddin Omon}

"Kichik ŭgil bir $\mathrm{k}_{1}$ anorčaga feat-Bulak žavdar non Turtle, tomork,asining xosili Bulgan kartoškalardan bir NECA dona ana va ozrok, olma šarbatidan solibdi. In the example given the meaning and content of the original was expressed quite differently in the target language. In the original there is no mention on "a few potatoes from his kitchen garden and a little apple juice", besides the words on the cabbage and the rabbit are absent in the translation. The addition by the translator of the words “қанорча" (bag), “жавдар" (rye bread) has led to the alteration of the content of the original work. The French use the words "galette", "la boule de pain", "baguette", "bread" to express bread, but none of these words means rye bread. The word "sound" means the piece of bread, but this is not the reason for translating as rye bread. The analysis of the variants of direct translation has shown that during the translation one observes the cases of the loss or the reduction of the content of the original and thus a good work turns into a mediocre work. One can not therefore achieve equivalence without having eliminated the dissonance. In translation it must always be remembered that "translation is the art of reconstruction, the interpretation of the original." In the examples mentioned above the translator has introduced into the translation text the words that do not exist in the original or in the version of the intermediate language which has led to the alteration of the form and content Of the original text. Second, the introduction of words expressing a shade of Eastern culture has led to its removal from the content of the original.

\section{The dissonances resulting from Mixture of national realities}

In cases where the translator replaces the notions of national realities of the original by the national realities of the language of arrival, there is also a phenomenon of cognitive dissonance in the reader's consciousness. The following example is taken from the fairy tale of Charles Perrault "Les Contes de ma mère l'Oye".

\section{In the original}

"We have had a beautiful baptism: we have given as godmother to the little princess seven fairies that were found in the country, so that each fairy gave a gift to the child.

\section{The translation of $\mathrm{Ch}$. Minovarov}

“Қirol cradle ty̆yi қilibdi, cradle ty̆yiga mamlakatdagi exceptionally sexrgar parilarni taklif қilibdilar. The translation of Mr. Kholbekov: "Podşo sevinganidan E-jurtni jiøiв wedding qiliв веriвdi. Qizaloqqa name qujiş marosimiga qilsin deB etti iqlimdan etti sehrgarni etiBdi burden. In the variants of the translation quoted above Ch.Minovarov, having replaced the expression of the original "a beautiful baptism" by the expression "бешик туийи" (cradle festival) tried to give the translated text The national character, and Kholbekov, having replaced this expression with the word "тўй", chose a good solution and succeeded in neutralizing the meaning of the expression. We have found the following explanation of the expression "a beautiful baptism" in the dictionary of the French language: Baptism n.m. Of the Baptistian Greek, to immerse. Sacrament of the Christian religion, 
which is the juridical and sacral sign of insertion into the Church; This ceremony Name of baptism: First name received at the time of baptism. The cradle is a special mechanism made of willow or mulberry $\log$ intended for the attachment of a small child and stir. In the eastern countries "бешик туийи" (cradle wedding) is a national ceremony on the occasion of the birth of the baby for the first time in the cradle and this festival is very rich in national rites. Every reader knows that the French baptize the baby in the church where the name is given. The baby is grown in a cradle. Usually the difference between tongues is manifested in the absence of notions related to traditions, rites of a people. These traditions and rites are unknown to other peoples. The words designating the notions of the life of peoples surely express the national character. The example cited in the translation linked with the ceremony of "бешик тўйи" (the cradle's wedding) of a French baby may seem like a scare to the Uzbek reader. It is for this reason that we can speak of dissonance in the consciousness of the reader. During the course of "Theory and Practice of Translation" and "Linguistic and Cultural Bases of Translation" we examined how each reader understands and appropriates the various examples. We have found that in most cases where there are inappropriate uses of the notions of national realities, readers have a dissonance, that is, they are not satisfied with the quality of the translated text. The analyzes of the fairy tale "Booted Kick" have well demonstrated the cases of dissonance. The fairy tale of Charles Perrault was translated into Uzbek by Ch.Minovarov and M.Kholbekov. The translation of Ch.Minovarov appeared under the name of "Master of the business, or Puss in Boots" "The Cat Master or Puss in Boots"), and the translation of Mr. Kholbekov under the name "Кот в сапогах". Let us give examples.

\section{In the original}

"The shares were soon made. The eldest had the mill, the second had the donkey, and the younger one had only the Cat ". The Minovarov translation: "The site merosnï qozïkalon éllikboşïnï çaqïrïb ŭtïrïşmay thetics taqsïmlab olïşïbdï”. The Kholbekov translation: "Zoo-ukalar y̆rtasida otadan qolgan inherited tezda taqsimlaniвdi: kattasi tegirmonni y̆rtancasi eşakni olibdi kenzasiga By̆lsa muşuk tegiBdi xolos." Although the two translations are made directly from the French language, in the first variant we see the remoteness of the original and the attempt to give the national character to the text. In Ch. Minovarov's translation there is an attempt to give the text a national character. In Kholbekov's translation there is a balance between meaning and content, the rules of equivalence are well respected. Here again we have convinced ourselves that if the translators respect the theoretical and practical rules of translation, they will be more likely to have an equivalence of translation. In the consciousness of the reader who reads the aforementioned texts will come a representation of the world of the Uzbeks, more precisely of the East. Because words such as “қозикалон”, “элликбоши”, “мингбоши”, “қози”, “имом”, “эшон" (The aged words meaning the prosecutor, connoisseur of the Koran etc.) are only proper to the mentality of the East and are very far from the way of life of the West. Now, "the translator, with his translation, passes the examination before thousands of readers. This calls for the highest responsibility. The careless translation, having not understood the essence of the work, can not pass this just examination. ". Translation creates the possibility for people who do not speak other languages to know their favorite works. Through the translated works they get to know the history and culture of another people. It is for these reasons that each translator must create a translation that is as close as possible to the original. Examples cited above can be used to draw the conclusion that, as a result of the replacement of the national realities of the original language by the national realities of the language of arrival or as a result of their mixing, the phenomenon of dissonance.

\section{Dissonances and the Translation of Proverbes}

One can not imagine a literary work without proverbs and sayings. Proverbs and proverb sayings are considered to be the language units used to improve and enrich the literary work and increase its value. Proverbs present the original world of each nation, that is, national values, customs, customs, traditions. In literary translation proverbs acquire a new life and a new color. The translation of proverbs and sayings presents a particular difficulty for the translator. The poor translation of these can cause the appearance of cognitive dissonance. For the argumentation of the ideas expressed, we quote the example of the translation of the story of Erkin A'zam "Pakananing ошиқ кўнгли" ("The loves of Courtaud"). In the original: Heel hisoвiga y̆sgan ky̆ngilni scent qilarkan little argument. Şunisi catoqki quropur ojoqni rosa qaqşatarkan, wet jurmaj akaşak вy̆liв qoladi. Lekin- nacora qurBonsiz oralaвa- oalaвami? Toqqa ciqmasangiz dy̆lona qajda! [3] The French translation: But the height of his heels wounded his selfesteem. On the other hand, his feet suffered atrociously. What could he do but grimace and endure without saying a word? Success before pleasure! [4]. We try to clarify, in what situations we use the Uzbek proverb “Жон куйдирмасанг жонона қайда, тоққа чиқмасанг дўлона қайда" ("If you will not refuse the pleasures of life, where can you see the beautiful woman, and if you do not go up the mountain, where can you see the hawthorn". This proverb is used when talking about a man who has assiduity and another lazy man. The proverb means that for the acquisition of something good one has to sweat on qch, one has to work well and one can not reach anything effortlessly. The French translator translates this proverb as follows: "Success before pleasure". If we translate this variant into Uzbek, it expresses the following meaning: "Рохатланишдан олдин ғалаба қилиш керак" ("Before enjoying, you must defeat."). However, in the French language there are proverbs which have almost the same meaning as the Uzbek proverb. For example, No pleasure without pain, "No good without pain" and "It is necessary to sow to collect". For the precision of the degree of equivalence of these proverbs, we consider it necessary to give their translation verbatim. The word-for-word translation of the first variant, that is, "No pleasure without pain" means “без движения ничего нельзя достичь" or "No good without pain" "Without difficulty there is nothing good" ou encore "good can be achieved only through the difficulties." La traduction mot à mot de "Il faut semer pour recueillir" est la suivante: "before you collect (harvest), it needs to sow." Taking into account the facts mentioned, in order to express exactly the meaning of the original, the translator would have chosen an equivalent that exists in French instead of inventing a new expression. Because the proverb "Success before pleasure" for the French reader, first, is unintelligible, second, it has reduced the artistic and aesthetic character of the work. If the translator had chosen instead of "Success before pleasure" the proverb "No pleasure without pain" or "No good without pain", it would have expressed exactly the will to say of the original and would have retained its content and its emotivity.

\section{Conclusion}

\section{The following example is in the original and concluded}

"zismonij Biron zihatdan IDB nuqsonli man, Bilingki ky̆pinca, grudging вy̆ladi. Baxilning esa ky̆karmas garden”. The translation variant: "People who suffer from a physical disability often become aggressive and wicked. They never find happiness or luck. In the given context the French translator translated the expression "Бахилнинг 
боғи куикармас" (“The garden of the miser never flourishes") as "They never find happiness or luck", that is to say "The aggressive and ferocious person will never attain happiness and success". In the French language there are variants "It is not rich that is chicken" or "Man chiche is never rich", which correspond entirely to the meaning and content of the given proverb. The word-for-word translation of the given proverb - "Avarice will never be rich" and "the avaricious will never make a fortune". Given these facts the variant chosen by the translator "They never find happiness or luck", in our opinion, is not quite suitable. Because the translator replaced the word "бахил" - "avaricious" with the words “баджахил, агрессив" - aggressive and wicked and emphasized that these people will never be happy and will have luck. In the example given, the author has shown through the proverb how our people have long looked at greedy, greedy, greedy, envious, jealous people. These bad characters often put people in delicate situations. But in the translation it was not well expressed. The analysis of the variants of the translation of the above passages has shown, in what degree the opinion of Alexander von Humboldt is timely in this respect: "First we must study the traits of lifestyle, customs and traditions, culture of the people who are the components of the language units, and after that we can rely on perception to create the image and Express it by the words. Language, from its earliest forms, is under the influence of the character signs of the people. It is worth quoting the words of $\mathrm{L}$. Barkhudarov: "The text of the translation can never be complete and absolutely equivalent to the text of the original. That is why, when translating from one language to another to minimize semantic losses, one of the senses must be sacrificed ". It should be emphasized that translators in most cases succeed in having an equivalence of form and content thanks to their excellent mastery of the trade. Indeed, the understanding of the author's idea, the resentment of the motif of the work and the animation of the work in another language requires the translator a great creative talent. The translator who has undertaken such a responsibility must accomplish his mission so that the reader does not have a different representation of the author and the work. The presence in translation of such defects, such as the non-conformity of proverbs, the misuse of phraseological units, the mixing of national realities testify to the presence of the phenomenon of dissonance in translation. Besides, in this chapter we have demonstrated, on the basis of the analysis of the examples, that indirect translation, that is to say through an intermediate language, can cause the appearance of cognitive elements. Each translator should not forget that dissonance is the element preventing equivalence of translation, and that in the translation process it is necessary as much as possible to reduce and eliminate them. The means proposed above will have the positive effect in eliminating certain defects in this field.

\section{References}

1. Mousakka K (2005) The basis of the theory of translation, Tochkent Science.

2. The Fairy Tales of Perrault (1968) Paris.

3. The Little Larousse (1993) Paris, Larousse Edition.

4. Mouhammedov N (1973) Art of Tarjima. Tochkent.

5. Humboldt V (1985) Language and Philosophy kultury. Moscou. 